\section{Expert Opinion Regarding Clinical and Other Outcome Considerations in the Formulary Review of Immune Globulin}

Gamma globulin is the treatment of choice for many primary immunodeficiencies (PIDs) and autoimmune diseases. ${ }^{1}$ Immune globulin intravenous (IGIV) products have been used for more than 25 years and are generally considered to be safe and well tolerated.

Because of differences in their manufacturing processes, IGIV products vary with respect to $\mathrm{pH}$, stabilizers (such as sugars or glycine), sodium content, and osmolality/osmolarity (Table 1). ${ }^{2-8}$ The variability among products can influence tolerability, particularly in patients with preexisting risk factors and in patients receiving high doses of IGIV. ${ }^{9-13}$ Estimates of the rate of adverse events (AEs) vary considerably ( $2 \%$ to $25 \%$ ), depending on the patient population. ${ }^{14}$ Some AEs are related to particular product characteristics, and the use of certain individual IGIV products can increase the risk for AEs..$^{10,15-17}$ However, IGIV products are typically selected for formulary inclusion based on cost and availability without consideration of product and patient characteristics that may be related to an increased risk of AEs. ${ }^{18}$

In May 2006, 10 experts in the field of IGIV therapy gathered in Miami, Florida, to participate in a roundtable. Funding for the expert roundtable and travel expenses was provided by Talecris Biotherapeutics, makers of Gamunex. These experts were included on the basis of their publication history and frequent participation in meetings concerning the use of IGIV. We convened to discuss the proper use of IGIV, particularly the patient- and product-related factors that should be considered during the formulary review process for IGIV products.

Our personal experience has been that a wide disparity exists in how formulary reviews are conducted. When discussing the formulary review process at each of our institutions, we agreed that drug reviews vary from regularly scheduled meetings that consider all IGIV products to ad hoc reviews that occur only when a new product becomes available. The formulary review process is further complicated by the fact that pharmacists may not have information concerning the risk factors that should be considered when IGIV products are selected for particular patients. Focusing on the collective expert opinion of the group and without a formal literature summary, we concluded that formulary decision makers must take into account that IGIV products are not generic and that each IGIV product has unique characteristics that may affect both tolerability and the global cost of IGIV therapy. We also emphasized the importance of consistently using a particular brand of IGIV and the risks involved in frequent product changes. Finally, we concluded that a systematic method should be used to evaluate IGIV preparations based on product characteristics, patient risk factors, and infusion-related considerations.

After the Expert Panel discussion, Dr. Sorensen drafted a conclusion statement, and all panelists were polled to determine whether each panelist agreed with the statement. We offer our consensus view on the evaluation process for IGIV products and our recommendations for the inclusion of clinical outcomes data alongside traditional considerations such as product acquisition cost and availability.

\section{Pharmacoeconomic Considerations in IGIV Product Choice}

Historically, the supply of IGIV has been limited ${ }^{19}$; therefore, the primary drivers for decisions on IGIV selection have been cost and availability. Pharmacoeconomic data are limited to 1 comparative study, which indicated that IGIV manufactured using a caprylate/chromatography process (IGIV-C) compared with IGIV manufactured using a solvent/detergent process (IGIV-SD) results in cost savings, primarily due to differences in the number of hospitalizations for AEs. ${ }^{20}$ Assuming equal pricing of both IGIV products, this multivariate analysis showed that annual mean per-participant costs were significantly lower between those receiving IGIV-C and those receiving IGIV-SD for prescription medications $(-\$ 302,95 \%$ confidence interval [CI], $-\$ 598$ to $-\$ 6)$, hospitalization $(-1,454,95 \% \mathrm{CI},-\$ 1,828$ to $-\$ 1,080)$, and total costs $(-\$ 1,304,95 \% \mathrm{CI},-\$ 1,867$ to $-\$ 742)$.

The average selling price of IGIV does not accurately reflect the total cost of treating a patient with that product. Directly identifiable costs, including preparation time and infusion time (in the outpatient setting), may also have an impact on total costs, although this amount has not been determined. In addition, product tolerability is not usually considered in the total cost of a given product. The overall cost of IGIV administration may be increased in a significant number of patients by tolerability problems common to all agents, such as fever, headache, and nausea (see the Infusion Rate section for further discussion) and occasionally by serious AEs. ${ }^{21,22}$ The formulary review process should ensure the availability of appropriate IGIV products to match patient-specific risk profiles to product-specific characteristics to reduce the risks and costs of tolerability problems and AEs (see Table 2).

\section{Formulary Review Process for IGIV}

Safety, effectiveness, and cost are the 3 types of information most commonly identified by formulary committees as necessary for making drug selections. ${ }^{23}$ To date, only 1 study has directly compared the clinical outcomes of treatment with different IGIV products. The results of that study indicated that IGIV-C had some advantages in preventing sinopulmonary infections compared with IGIV-SD. ${ }^{24}$ Comparative efficacy data for other IGIV products are not available.

In our experience, safety and tolerability data for different IGIV products are not reviewed in a consistent manner during the formulary review process. For example, low or no sugar content may be considered key to good tolerability by some formulary review committees, while other committees may focus on physiologic osmolality. A number of IGIV characteristics 


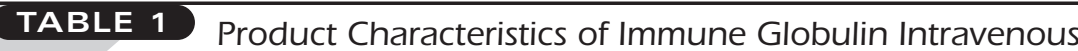

\begin{tabular}{|c|c|c|c|c|c|c|}
\hline Product Specifics & $\begin{array}{c}\text { Talecris } \\
\text { Gamunex }{ }^{2} \\
\text { Immune Globulin } \\
\text { Intravenous } \\
\text { (Human), 10\% } \\
\text { Caprylate/ } \\
\text { Chromatography } \\
\text { Purified }\end{array}$ & $\begin{array}{c}\text { Baxter } \\
\text { Gammagard } \\
\text { Liquid }^{3} \\
\text { Immune Globulin } \\
\text { Intravenous } \\
\text { (Human) } 10 \%\end{array}$ & $\begin{array}{c}\text { Baxter } \\
\text { Gammagard S/D } \\
\text { Immune Globulin } \\
\text { Intravenous } \\
\text { (Human) }\end{array}$ & $\begin{array}{c}\text { ZLB Behring } \\
\text { Carimune NF5 } \\
\text { Nanofiltered } \\
\text { Immune Globulin } \\
\text { Intravenous } \\
\text { (Human) }\end{array}$ & $\begin{array}{c}\text { Grifols } \\
\text { Flebogamma }{ }^{6} 5 \% \\
\text { Immune Globulin } \\
\text { Intravenous } \\
\text { (Human) }\end{array}$ & $\begin{array}{c}\text { Octapharma } \\
\text { Octagam }^{7} \\
\text { Immune Globulin } \\
\text { Intravenous } \\
\text { (Human) } 5 \%\end{array}$ \\
\hline $\begin{array}{l}\text { Average selling } \\
\text { price* per gram }^{8}(\$)\end{array}$ & 60.89 & 60.89 & 51.20 & 51.20 & 60.89 & 60.89 \\
\hline Form & Liquid 10\% & Liquid 10\% & Lyophilized & Lyophilized & Liquid 5\% & Liquid 5\% \\
\hline Preparation time & Ready to use & Ready to use & $\begin{array}{l}\text { Unknown, must be } \\
\text { dissolved }\end{array}$ & Up to 20 minutes & Ready to use & Ready to use \\
\hline Indications & PID, ITP & $\begin{array}{l}\text { PID associated } \\
\text { with defects } \\
\text { in humoral } \\
\text { immunity }\end{array}$ & $\begin{array}{l}\text { PID, ITP, CLL, } \\
\text { Kawasaki syndrome }\end{array}$ & $\begin{array}{l}\text { Immunodeficiency, } \\
\text { ITP }\end{array}$ & PID & PID \\
\hline Sugar content & No sugar & No added sugar & $\begin{array}{l}20 \mathrm{mg} / \mathrm{mL} \text { glucose } \\
\text { in a } 5 \% \text { solution }\end{array}$ & $\begin{array}{l}1.67 \mathrm{~g} \text { sucrose } \\
\text { per g protein }\end{array}$ & $\begin{array}{l}50 \mathrm{mg} / \mathrm{mL} \\
\text { D-sorbitol }\end{array}$ & $\begin{array}{l}100 \mathrm{mg} / \mathrm{mL} \\
\text { maltose }\end{array}$ \\
\hline Sodium content & Trace amounts & No added sodium & $\begin{array}{l}\text { Approximately } \\
8.5 \mathrm{mg} / \mathrm{mL} \text { sodium } \\
\text { chloride }\end{array}$ & $\begin{array}{l}<20 \text { mg sodium } \\
\text { chloride } \\
\text { per g protein }\end{array}$ & $\begin{array}{l}<3.2 \mathrm{mEq} / \mathrm{L} \\
(<0.02 \%)\end{array}$ & $\leq 30 \mathrm{mmol} / \mathrm{L}$ \\
\hline $\begin{array}{l}\text { TSE removal } \\
\text { labeling }\end{array}$ & Yes & No & No & Yes & No & No \\
\hline $\begin{array}{l}\text { pH when liquid } \\
\text { (goal 4.0-5.0) }\end{array}$ & $4.0-4.5$ & $4.6-5.1$ & $6.4-7.2$ & $6.4-6.8$ & $5.0-6.0$ & $5.1-6.0$ \\
\hline $\begin{array}{l}\text { Osmolality/ } \\
\text { Osmolarity } \\
\text { (goal 280-300) }\end{array}$ & $258 \mathrm{mOsm} / \mathrm{kg}$ & 240-300 mOsm/kg & $\begin{array}{l}636 \mathrm{mOsm} / \mathrm{L}(5 \%) \\
1250 \mathrm{mOsm} / \mathrm{L}(10 \%)\end{array}$ & $\begin{array}{l}384 \mathrm{mOsm} / \mathrm{kg}(6 \%) \dagger \\
768 \mathrm{mOsm} / \mathrm{kg}(12 \%) \dagger\end{array}$ & $240-350 \mathrm{mOsm} / \mathrm{L}$ & $310-380 \mathrm{mOsm} / \mathrm{kg}$ \\
\hline $\begin{array}{l}\text { Maximum } \\
\text { infusion rate } \\
(\mathrm{mL} / \mathrm{kg} / \mathrm{min})\end{array}$ & 0.08 & $0.083 \mp$ & $\begin{array}{l}0.067 \dagger(5 \%) \S \\
0.13 \dagger(10 \%) \S\end{array}$ & $\begin{array}{l}\text { See calculations } \\
\text { in prescribing } \\
\text { information. }\end{array}$ & 0.10 & 0.07 \\
\hline $\begin{array}{l}\text { Tamper-evident } \\
\text { vials }\end{array}$ & Yes & Yes & Yes & Yes & No & Yes \\
\hline $\begin{array}{l}\text { Shelf life/storage } \\
\text { requirements }\end{array}$ & $\begin{array}{l}36 \text { months } \\
\text { at refrigerated } \\
\text { temperature } 2^{\circ}-8^{\circ} \mathrm{C} \\
\left(36^{\circ}-46^{\circ} \mathrm{F}\right) ; \text { up to } \\
6 \text { months at } 25^{\circ} \mathrm{C} \\
\left(77^{\circ} \mathrm{F}\right) \text {; } \\
\text { do not freeze }\end{array}$ & $\begin{array}{l}36 \text { months } \\
\text { at refrigerated } \\
\text { temperature } \\
2^{\circ}-8^{\circ} \mathrm{C}\left(36^{\circ}-46^{\circ} \mathrm{F}\right) \text {; } \\
\text { up to } 9 \text { months at } \\
\text { room temperature } \\
\text { within first } \\
24 \text { months of the } \\
\text { date of } \\
\text { manufacture; do } \\
\text { not freeze }\end{array}$ & $\begin{array}{l}24 \text { months } \\
\text { Temperature } \\
\text { not to exceed } \\
25^{\circ} \mathrm{C}\left(77^{\circ} \mathrm{F}\right) \\
\text { do not freeze }\end{array}$ & $\begin{array}{l}24 \text { months } \\
\text { Room temperature, } \\
\text { not to exceed } 30^{\circ} \mathrm{C} \\
\left(86^{\circ} \mathrm{F}\right) \text {; do not freeze }\end{array}$ & $\begin{array}{l}24 \text { months } \\
\text { Temperature, } \\
2^{\circ}-25^{\circ} \mathrm{C}\left(36^{\circ}-77^{\circ} \mathrm{F}\right) \text {; } \\
\text { do not freeze }\end{array}$ & $\begin{array}{l}24 \text { months at } \\
\text { refrigerated } \\
\text { temperature } \\
2^{\circ}-8^{\circ} \mathrm{C}\left(36^{\circ}-46^{\circ} \mathrm{F}\right) \text {; } \\
\text { up to } 18 \text { months } \\
\text { from date of } \\
\text { manufacture at } \\
\text { temperatures } \\
\text { not to exceed } \\
25^{\circ} \mathrm{C}\left(77^{\circ} \mathrm{F}\right) \text {; do } \\
\text { not freeze }\end{array}$ \\
\hline $\begin{array}{l}\text { Maximum } \\
\text { recommended } \\
\text { dose }\end{array}$ & $\begin{array}{l}\text { PID: } 300-600 \mathrm{mg} / \mathrm{kg} \\
\text { ITP: } 2 \text { g/kg divided } \\
\text { into } 2 \text { doses of } 1 \mathrm{~g} / \mathrm{kg} \\
\text { on consecutive days } \\
\text { or into } 5 \text { doses of } \\
0.4 \mathrm{~g} / \mathrm{kg} \text { given on } \\
5 \text { consecutive days }\end{array}$ & $\begin{array}{l}\text { PID: } 300-600 \mathrm{mg} / \mathrm{kg} \\
\text { ITP: not indicated }\end{array}$ & $\begin{array}{l}\text { PID: } 300-600 \mathrm{mg} / \mathrm{kg} \\
\text { ITP: a dose of } \\
1 \mathrm{~g} / \mathrm{kg} \text { is } \\
\text { recommended }\end{array}$ & $\begin{array}{l}\text { PID: } 0.4 \mathrm{~g} / \mathrm{kg} \\
\text { ITP: } 0.4 \mathrm{~g} / \mathrm{kg} \text { on } \\
2-5 \text { consecutive days }\end{array}$ & $\begin{array}{l}\text { PID: } 300-600 \mathrm{mg} / \mathrm{kg} \\
\text { ITP: not indicated }\end{array}$ & $\begin{array}{l}\text { PID: } 300-600 \mathrm{mg} / \mathrm{kg} \\
\text { ITP: not indicated }\end{array}$ \\
\hline $\begin{array}{l}\text { Package sizes in } \\
\text { grams }\end{array}$ & $1,2.5,5,10,20$ & $1,2.5,5,10,20$ & $2.5,5,10$ & $1,3,6,12$ & $0.5,2.5,5,10$ & $1,2.5,5,10$ \\
\hline
\end{tabular}

* Current for January 2007 to March 2007. The Centers for Medicare E Medicaid Services average selling price lags by one quarter.

+ Dependent on diluent used.

\# Converted from $8.9 \mathrm{mg} / \mathrm{kg} / \mathrm{min}$.

$\S$ Converted from $4 \mathrm{~mL} / \mathrm{kg} / \mathrm{h}(5 \%), 8 \mathrm{~mL} / \mathrm{kg} / \mathrm{h}(10 \%)$.

$C L L=$ chronic lymphocytic leukemia; ITP=idiopathic thrombocytopenic purpura; $P I D=$ primary immunodeficiency; S/D=solvent/detergent;

TSE $=$ transmissible spongiform encephalopathy. 
TABLE 2 Patient and Immune Globulin Intravenous Risk Factors

\begin{tabular}{l|c|c|c|c}
\hline \multirow{2}{*}{ Patient Risk Factors* } & \multicolumn{4}{|c}{ IGIV Risk Factors } \\
\cline { 2 - 6 } & Volume Load & $\begin{array}{c}\text { Sugar Content } \\
\text { (None) }\end{array}$ & $\begin{array}{c}\text { Sodium Content } \\
\text { (None or Trace Amounts) }\end{array}$ & $\begin{array}{c}\text { Osmolality } \\
(<300 \mathrm{mOsm} / \mathrm{kg})\end{array}$ \\
\hline Cardiac impairment & $\mathrm{X}$ & $\mathrm{X}$ & $\mathrm{X}$ & $\mathrm{X}$ \\
\hline Renal dysfunction & $\mathrm{X}$ & $\mathrm{X}$ & $\mathrm{X}$ & $\mathrm{X}$ \\
\hline Thromboembolic risk & $\mathrm{X}$ & $\mathrm{X}$ & $\mathrm{X}$ & $\mathrm{X}$ \\
\hline Diabetes & $\mathrm{X}$ & $\mathrm{X}$ & $\mathrm{X}$ \\
\hline Vascular disease & $\mathrm{X}$ & $\mathrm{X}$ & $\mathrm{X}$ & $\mathrm{X}$ \\
\hline Elderly $(>60$ years) & $\mathrm{X}$ & & $\mathrm{X}$ & $\mathrm{X}$ \\
\hline Neonates & & & $\mathrm{X}$ \\
\hline
\end{tabular}

* All patient comorbid conditions must be considered when making a product selection.

Cardiac impairment = history of myocardial infarction, congestive heart failure, or decreased ejection fraction.

Renal dysfunction= creatine 1.5 and greater.

Thromboembolic risk = history of thromboembolic disease, myocardial infarction, or stroke.

Diabetes= type 1 or type 2 requiring treatment.

Vascular disease $=$ prior history of stroke, myocardial infarction, peripheral vascular disease.

Low risk levels for IGIV risk factors are indicated within ().

that vary among products have been linked to AEs, such as the association of IGIV products stabilized with sugar and acute renal failure. ${ }^{15,17}$ Similarly, hyperosmolality may be correlated with thromboembolic events. ${ }^{16,25}$ For consistent and thorough review, all significant product characteristics that influence tolerability and the risk for AEs should be considered during the formulary review process.

Our experience has been that IGIV products differ with regard to AE risk and that the risk of AEs should be considered the driving force in the choice of a particular IGIV product. The following criteria should be considered when evaluating IGIV products (Table 1): pH, added stabilizers, osmolality/osmolarity, formulation, concentration, volume load, and infusion rate.

\section{IGIV Product Considerations}

\section{Stabilizers}

The formation of immunoglobulin (Ig) multimers may lead to aggregation, resulting in both loss of function and increased side effects; therefore, IGIV manufacturers must employ methods to prevent Ig from aggregating. ${ }^{26}$ The optimal $\mathrm{pH}$ to prevent aggregation of IgG is 4-4.5. ${ }^{27}$ Two brands of IGIV are supplied at $\mathrm{pH} 4-5$ (Table 1). ${ }^{2-7}$ When the $\mathrm{pH}$ is above 5, IGIV requires stabilizing sugars such as glucose, sucrose, sorbitol, or maltose.

Patients with renal dysfunction or diabetes, as well as the elderly, may require special consideration with respect to the use of IGIV containing sugars, although absolute AEs have not been demonstrated to date. ${ }^{9,12,14}$ While the incidence (denominator) of IGIV-associated renal AEs is not known, data from the Centers for Disease Control and Prevention indicate that 90\% of IGIVassociated renal AEs occurred when products stabilized with sucrose were used; the relative frequency of sucrose-stabilized IVIG use versus other IVIG products was unknown. Of patients who experienced renal AEs, 59\% had 1 or more of the following risk factors: prior renal insufficiency, diabetes, or advanced age $\left(>65\right.$ years) ${ }^{17}$

\section{Osmolarity/0smolality}

Osmolality is the concentration of osmotically active particles in a solution and is equal to the sum of the osmoles of all the solutes in a solution. Major contributors to osmolality include sodium, sugars, and other solutes (proteins such as albumin). ${ }^{16}$ Physiologic osmolality is $280-296 \mathrm{mOsm} / \mathrm{kg}$. IGIV solutions range in osmolality from physiologic values to approximately $1250 \mathrm{mOsm} / \mathrm{L}$ (Table 1). ${ }^{2-7}$

When infused intravenously, hyperosmolar solutions may contribute to hemodynamic changes, thus theoretically increasing the risk of infusion-related AEs. ${ }^{13,21,25}$ For example, in a study of IGIV patients at Wake Forest University Baptist Medical Center over a 4-year period, Caress et al. determined that $0.6 \%$ of patients who received IGIV (of undetermined osmolality content) experienced a stroke. The authors stated that this high rate of stroke might be because patients receiving IGIV in the hospital setting tend to have more risk factors than nonhospitalized patients. ${ }^{25}$ High osmolality may increase the risk for AEs in patients with cardiac impairment, renal dysfunction, or high risk of a thromboembolic event. High osmolality also increases the risk of AEs in the elderly and in neonates. ${ }^{28,29}$

Lyophilized products that are reconstituted at high concentrations to decrease volume load create solutions with a higher osmolality that may cause increased serum viscosity, 
which further increases the risk for thromboembolic events. ${ }^{9,30,31}$ To decrease the conjectured risk of osmolality-related AEs, we recommend using liquid IGIV products of normal physiologic osmolality or lyophilized IGIV products that are reconstituted to a volume high enough to create a preparation of physiologic osmolality in patients at risk for osmolality-related AEs. In patients at risk for volume overload, a high-concentration product, which should be infused slowly, may be appropriate.

\section{Formulation}

IGIV is available in both liquid and lyophilized forms. Liquid formulations are sold at a 5\% or 10\% fixed concentration and are ready to use. The time between the implementation of a pharmacy order and the start of the infusion is shortened by using liquid formulations instead of lyophilized products; some lyophilized products take up to 20 minutes to dissolve. ${ }^{5}$ The staff time spent preparing the lyophilized product is not reimbursed by Medicare or other insurance providers, resulting in unreimbursed costs for the pharmacy, clinic, or clinician. Lyophilized products reconstituted at higher than 5\% concentrations will have higher than normal physiologic osmolality and may increase the risk of AEs (Table 1). . $^{27,13,21,25,30}$

\section{Concentration and Volume Load}

The IGIV dose for a given condition and the concentration of the IGIV preparation influence both the total volume and the time of infusion. There is an inverse correlation between the concentration of an IGIV product and the length of a typical infusion. While recommended maximum infusion rates vary for different products and for each patient, in general, a more concentrated product will allow for both a lower total fluid volume and a shorter infusion time. For example, assuming the same rate of infusion, a product at a concentration of $10 \%$ will require half the infusion time of a product at a concentration of $5 \%$. The product at $10 \%$ concentration will lead to decreased nursing and infusion room time, ultimately leading to a projected but undeterminable reduction in the overall cost of IGIV treatment, particularly in the outpatient setting.

Liquid IGIV products are ready to use at 5\% (Flebogamma and Octogam) or 10\% (Gamunex and Gammagard Liquid) con-centration and cannot be concentrated further. Lyophilized products are also available (Gammagard S/D and Carimune NF). The practice of reconstituting lyophilized IGIV products to a concentration greater than that recommended in the package insert in order to decrease volume and reduce infusion time must be weighed against the higher risks for AEs from the resulting increase in osmolality. Rapidly delivering lyophilized IGIV at high concentrations may also result in increased serum viscosity, which is associated with thromboembolic events such as stroke in patients with preexisting vascular disease. ${ }^{13,32,33}$ Volume status must also be monitored when larger doses of IGIV are administered to elderly patients, ${ }^{16}$ debilitated patients, or neonates. ${ }^{16}$

\section{Infusion Rate}

Rapid infusion rates are associated with several common mild or "rate-related" AEs that decrease tolerability. These include low-grade fever, headache, nausea, malaise, arthralgia, chest pain and tightness, rashes, hypotension, and myalgia. ${ }^{11,14}$ Maximum possible infusion rates are listed in Table 1 , and range from 0.067 to $0.1 \mathrm{ml} / \mathrm{kg} / \mathrm{min}$. Diagnosis, treatment, and monitoring of patients experiencing these AEs increase the total cost of treatment. Therefore, adjustment of the infusion rate and the choice of product must be carefully monitored to decrease tolerability problems. If patients experience any of the side effects noted above, the providers are advised to slow the rate of infusion and/or use preinfusion medications such as diphenhydramine, acetaminophen, nonsteroidal antiinflammatory drugs, or corticosteroids before initiating the IGIV infusion. ${ }^{11}$ Change of product may also affect the tolerability of IGIV for individual patients. Switching to a different IGIV product is recommended when the patient exhibits repeated adverse reactions to an IGIV product despite infusion rate adjustments and the use of preinfusion medications. If these events continue with all IGIV products, it may be necessary to use an alternative route of administration or discontinue treatment. An initial decrease in infusion rate is recommended when a new product is used.

\section{Pathogen Safety}

Because IGIVs are derived from blood, decreasing the risk of infection is of the utmost importance. To prevent transmission of blood-borne pathogens, the manufacturers of all IGIV products incorporate processes that ensure viral inactivation and removal. ${ }^{34}$ Prion contamination has also become a theoretical concern in recent years, ${ }^{9}$ and some IGIV manufacturers have incorporated prion contaminant removal measures-cloth filtration and depth filtration-into the IGIV manufacturing process. ${ }^{34}$ Two of the 6 commercially available IGIV products have been manufactured using methods with demonstrated prion removal capabilities (Table 1); however, no documented cases of prion contamination from IGIV or other blood products have been reported, regardless of manufacturing technique. ${ }^{2,5}$

\section{FDA-Licensed Indications}

The various brands of IGIV are licensed for different indications, including PID (all brands), idiopathic thrombocytopenic purpura ([ITP] Gammagard S/D, Gamunex, Carimune), chronic lymphocytic leukemia (Gammagard S/D), and Kawasaki syndrome (Gammagard S/D). For a full listing of U.S. Food and Drug Administration (FDA)-licensed indications for each brand of IGIV, see Table 1.

\section{Dose, Package Size, and Storage}

Other IGIV product choice considerations include dose, package size, and storage. The maximum recommended doses 
of IGIV for PID and ITP are similar for the different brands of IGIV, and a range of package sizes is available for most brands (Table 1). ${ }^{2-7}$ Because larger doses $(1-2 \mathrm{~g} / \mathrm{kg})$ are recommended for ITP, ${ }^{35}$ package size and formulation may be a relevant consideration for this indication since staff may be required to pool several vials for a single dose. To be certain of package content and sterility, patients should use IGIV products packaged in tamper-evident vials whenever possible.

\section{Underlying Risk Factors Necessitating Specific IGIV Product Choice}

A number of underlying risk factors (Table 2), including cardiac impairment, renal dysfunction, IgA deficiency, thromboembolic risk, diabetes, vascular disease, age (neonates and the elderly), and a history of AEs, may signal caution for the use of certain IGIV products. If any of these risk factors exist, IGIV products should be carefully selected to minimize risk. While serious AEs are rare, they can occur upon first administration of IGIV, ${ }^{25}$ so risk factors need to be carefully assessed for all patients. Formulary committees may consider requiring a risk assessment form as part of the order for IGIV. In cases where risk factors are identified, an immunologist should be consulted when selecting an IGIV brand.

\section{Recommendations and Future Directions for IGIV Formulary Reviews}

To improve the formulary review process, we recommend that (1) reviews include a comprehensive evaluation of all available products, (2) reviews occur annually, and (3) immunologists and other experienced IGIV users be included as primary reviewers and decision makers in IGIV product selection.

Selection of IGIV products should be made according to patient-specific risk factors, product-specific characteristics, and practical considerations such as cost and convenience. We recommend using a risk assessment form to evaluate each patient regardless of infusion setting. This form, to be reviewed by both the physician and the pharmacist, should help decide whether IGIV use is appropriate for the patient and which IGIV preparation to select on the basis of particular risk factors (Table 2). Ideally, the risk assessment form would be computerized to facilitate the exchange of information between physician and pharmacist. Infusion- and dose-related AEs are also important considerations, as are practical concerns such as ease of use (e.g., storage requirements, time required for product preparation before administration), ease of administration (solution concentration), and duration of infusion.

The IGIV formulary determination process must ensure that at least 1 of the brands selected for formulary inclusion is able to minimize AE-related risks in patients and provide clinicians with appropriate IGIV brand choices. This will allow clinicians and pharmacists to select appropriate IGIV products based on patient-specific risk factors.
Future initiatives to improve the formulary selection process should include more complete recording, coding, and reporting of AEs, which will result in a more informative picture of the specific AEs associated with particular IGIV products. We also call for prospective studies to evaluate clinical and pharmacoeconomic outcomes for all individual brand IGIV products.

\section{Conclusions}

IGIV formulary decision makers should select an adequate number of IGIV brands with different product characteristics for formulary inclusion to enable clinicians and pharmacists to match IGIV products to specific patients based on patient-risk profiles. The panel participants concur that at least 2 brands should be included, and some authors feel that up to 4 brands are necessary.

Individual IGIV brands have distinctly different characteristics. Products differ in their preparation and infusion times. These differences may affect the cost of administration and the risk of AEs that may be associated with their use, although neither the relative administrative costs nor the risk of AEs has been quantified. Patients vary in their responses to different products; therefore, each patient must be individually matched with the most appropriate IGIV product by the physician and pharmacist. Prudent, specific IGIV product selection that compares patient tolerability and risk profiles will result in better tolerability and lower risk for AEs, improving patient outcomes. Better IGIV infusion experiences together with more practical dosing and infusion rates may produce better patient outcomes and reduce overall costs associated with IGIV therapy.

Ricardo Sorensen, MD
Chairman, Department of Pediatrics
Louisiana State University Health Sciences Center
Children's Hospital New Orleans
200 Henry Clay Ave.
New Orleans, LA 70118
E-mail: rsoren@lsuhsc.edu

\section{COMMENTARY COAUTHORS}

Chitra Dinakar, MD, associate professor, Department of Pediatrics, Section of Allergy/Immunology, University of Missouri-Kansas City

Ramsay Fuleihan, MD, associate research scientist, Section of Immunology and Yale Child Health Research Center, New Haven, Connecticut

Sudhir Gupta, MD, PhD, professor of medicine, pathology, microbiology, and molecular genetics, University of California-Irvine

Alan Knutsen, MD, professor of pediatrics, Saint Louis University Medical School, Missouri

Roger Kobayashi, MD, clinical professor of pediatrics, University of CaliforniaLos Angeles School of Medicine

Carol Lee Koski, MD, professor of neurology (retired), University of Maryland Medical Center, Baltimore 
Arnold I. Levinson, MD, professor of medicine and neurology and chief, Allergy and Immunology Section, University of Pennsylvania Medical Center, Philadelphia

Ralph Shapiro, MD, director of Midwest Immunology Clinic, Plymouth, Minnesota

Richard L.Wasserman, MD, PhD, clinical professor of pediatrics, University of Texas Southwestern Medical School, Dallas

(Ricardo Sorensen, MD, is also a member of the Section of Allergy/Immunology, LSU Health Sciences Center, Children's Hospital New Orleans, Louisiana.)

\section{ACKNOWLEDGMENT}

The authors thank Annie Neild, PPSI, Stamford, Connecticut, for editorial assistance.

\section{DISCLOSURES}

All authors received honoraria to attend the meeting of the Expert Panel, and their travel expenses were reimbursed by Talecris Biotherapeutics. Sorensen received grant funds from Talecris Biotherapeutics; Fuleihan received grant funds from Talecris Biotherapeutics; Kobayashi is a consultant for the American Red Cross, the Shanghai Red Cross, ZLB Behring, Bayer, and Talecris Biotherapeutics; Koski is a consultant for Talecris Biotherapeutics and Baxter; Levinson is a consultant for Talecris Biotherapeutics and Centocor; Shapiro is a consultant for ZLB Behring, Talecris Biotherapeutics, Baxter, and Biogen and a speaker for ZLB Behring, Talecris, and Biogen; and Wasserman is a consultant and speaker for ZLB Behring and Talecris Biotherapeutics and has received grant funds from ZLB Behring, Talecris Biotherapeutics, Baxter Healthcare, and FFF Enterprises.

\section{REFERENCES}

1. Orange JS, Hossny EM, Weiler CR, et al. Use of intravenous immunoglobulin in human disease: a review of evidence by members of the Primary Immunodeficiency Committee of the American Academy of Allergy, Asthma and Immunology. J Allergy Clin Immunol. 2006;117(4 suppl):S525-S553.

2. Gamunex [package insert]. Research Triangle Park, NC: Talecris Biotherapeutics; 2005.

3. Gammagard Liquid [package insert]. Westlake Village, CA: Baxter Healthcare Corporation; 2005.

4. Gammagard S/D [package insert]. Westlake Village, CA: Baxter Healthcare Corporation; 2005.

5. Carimune NF [package insert]. Kankakee, IL: ZLB Behring; 2005.

6. Flebogamma [package insert]. Los Angeles, CA: Grifolos Biologicals, Inc; 2004.

7. Octagam [package insert]. Centreville, VA: Octapharma USA, Inc; 2005.

8. Payment allowance limits for Medicare part B drugs. Available at: http:// www.cms.hhs.gov. Accessed January 25, 2007.

9. Nydegger UE, Sturzenegger M. Adverse effects of intravenous immunoglobulin therapy. Drug Saf. 1999;21(3):171-85.

10. Haskin JA, Warner DJ, Blank DU. Acute renal failure after large doses of intravenous immune globulin. Ann Pharmacother. 1999;33(7-8):800-03.

11. Hamrock DJ. Adverse events associated with intravenous immunoglobulin therapy. Int Immunopharmacol. 2006;6(4):535-42.

12. Epstein JS, Zoon KC. Important drug warning: Immune Globulin Intravenous (human) (IGIV) products. Neonatal Netw. 2000;19(2):60-62.

13. Dalakas MC. High-dose intravenous immunoglobulin and serum viscosity: risk of precipitating thromboembolic events. Neurology. 1994;44(2):223-26.

14. Pierce LR, Jain N. Risks associated with the use of intravenous immunoglobulin. Transfus Med Rev. 2003;17(4):241-51.
15. Shah S, Vervan M. Use of I.V. immune globulin and occurrence of associated acute renal failure and thrombosis. Am J Health Syst Pharm. 2005;62(7):720-25.

16. Gelfand EW. Differences between IGIV products: impact on clinical outcome. Int Immunopharmacol. 2006;6(4):592-99.

17. Centers for Disease Control and Prevention. Renal insufficiency and failure associated with immune globulin intravenous therapy-United States, 19851998. MMWR Morb Mortal Wkly Rep. 1999;48(24):518-21.

18. Mahadevia PJ. The pocketbook: pharmacoeconomic issues related to intravenous immunoglobulin therapy. Pharmacotherapy. 2005;25(11 pt 2): 94S-100S.

19. Wills AJ, Unsworth DJ. A practical approach to the use of intravenous immunoglobulin in neurological disease. Eur Neurol. 1998;39(1):3-8.

20. Mahadevia PJ, Strell J, Kunaprayoon D, Gelfand E. Cost savings from intravenous immunoglobulin manufactured from chromotography/caprylate (IGIV-C) in persons with primary humoral immunodeficiency disorder. Value Health. 2005;8(4):488-94.

21. Dalakas MC, Clark WM. Strokes, thromboembolic events, and IVIg: rare incidents blemish an excellent safety record. Neurology. 2003;60(11):1736-37.

22. Shah S. Pharmacy considerations for the use of IGIV therapy. Am J Health Syst Pharm. 2005;62(16 suppl 3):S5-S11.

23. Weekes LM, Day RO. The application of adverse drug reaction data to drug choice decisions made by pharmacy and therapeutics committees. An Australian perspective. Drug Saf. 1998;18(3):153-59.

24. Roifman CM, Schroeder H, Berger M, et al. Comparison of the efficacy of IGIV-C, 10\% (caprylate/chromatography) and IGIV-SD, 10\% as replacement therapy in primary immune deficiency. A randomized double-blind trial. Int Immunopharmacol. 2003;3(9):1325-33.

25. Caress JB, Cartwright MS, Donofrio PD, Peacock JE, Jr. The clinical features of 16 cases of stroke associated with administration of IVIg. Neurology. 2003;60(11):1822-24

26. Day NK, Good RA, Wahn V. Adverse reactions in selected patients following intravenous infusions of gamma globulin. Am J Med. 1984;76(3A):25-32.

27. Schwartz RS. Overview of the biochemistry and safety of a new native intravenous gamma globulin, IGIV, pH 4.25. Am J Med. 1987;83:46-51.

28. Siegel J. The product: all intravenous immunoglobulins are not equivalent. Pharmacotherapy. 2005;25(11 pt 2):78S-84S.

29. Vucic S, Chong PS, Dawson KT, Cudkowicz M, Cros D. Thromboembolic complications of intravenous immunoglobulin treatment. Eur Neurol. 2004; 52(3):141-44.

30. Jordan S, Cunningham-Rundles C, McEwan R. Utility of intravenous immune globulin in kidney transplantation: efficacy, safety, and cost implications. Am J Transplant. 2003;3(6):653-64.

31. Reinhart WH, Berchtold PE. Effect of high-dose intravenous immunoglobulin therapy on blood rheology. Lancet. 1992;339(8794):662-64.

32. Woodruff RK, Grigg AP, Firkin FC, Smith IL. Fatal thrombotic events during treatment of autoimmune thrombocytopenia with intravenous immunoglobulin in elderly patients. Lancet. 1986;2(8500):217-18.

33. Zaidan R, Al Moallem M, Wani BA, et al. Thrombosis complicating high dose intravenous immunoglobulin: report of three cases and review of the literature. Eur J Neurol. 2003;10(4):367-72.

34. Schleis TG. The process: new methods of purification and viral safety. Pharmacotherapy. 2005;25(11 pt 2):73S-7S.

35. National Institutes of Health. National Institutes of Health Consensus Development Conference. Intravenous immune globulin: prevention and treatment of disease. NIH consensus development conference statement. May 21-23, 1990. Available at: http://consensus.nih.gov/1990/

1990IntravenousImmunoglobulin 080html.htm. Accessed July 10, 2006. 